\title{
CHANGES OF ACTIVE COMPOUNDS IN APRICOT FRUITS CAUSED BY STORAGE DEPEND ON CHARACTERISTIC FEATURES OF VARIETIES
}

\section{L.D. CHALAYA, T.G. PRICHKO}

North-Caucasian Zonal Research Institute of Orcharding and Viniculture, Federal Agency of Scientific Organizations, 39, ul. Pobedy, Krasnodar, 350901 Russia, e-mail kubansad@kubannet.ru, prichko@yandex.ru Received December 5, 2013

\begin{abstract}
Apricots (Armeniaca vulgaris Lam.) contain a wide variety of nutrients such as sugars and acids, and preventive bioactive compounds such as vitamins, polyphenols and pectins which possess antioxidant activity and affect shelf life of fruits. Like other biological features, these properties are hereditarily determined. Therefore, proper selection of varieties, in addition to the optimal mode of storage, can help to reduce losses in commercial properties and deterioration of the chemical composition of apricots during storage because of rots, physiological diseases, and natural attrition. The article presents a comparative evaluation of the chemical composition and keeping quality of fruits in most common apricot varieties from Krasnodar region that are well adapted to the local conditions of growing. They are the Pineapple, Emerald, Red-Cheeked, Sunny, Amber, ripening in the second ten days of July, and the Krasnodar late, ripening in the third week of July. The differences in many chemical components of fruits peculiar to varieties have been found. An amount of soluble solids in the fruit ranged from 13.5 in Emerald variety to $18.8 \%$ in Pineapple, and the sugars varied from 9.5 to $13.6 \%$, respectively. Apricot is a high acidic culture with fruits which can contain from 1.4 to $2.0 \%$ organic acids. The high content of pectin at more than $1.0 \%$ was also observed. Pineapple and Sunny varieties accumulated a significant amount of ascorbic acids which was superior to an average value of $14.0 \mathrm{mg} / 100 \mathrm{~g}$ for the central zone of the Krasnodar region. P-active catechins were detected in fruits at 45.6 to $155.9 \mathrm{mg} / 100 \mathrm{~g}$. The high content of catechins at more than $100.0 \mathrm{mg} / 100 \mathrm{~g}$ was observed in Emerald, Red-Cheeked and Amber varieties. In the Pineapple variety the vitamin PP level of $0.6 \mathrm{mg} / 100 \mathrm{~g}$ was detected. According to L.V. Metlitskii (1976) vitamin $\mathrm{PP}$ is a component of many enzymes involved in cellular respiration, metabolism of proteins, and regulation of nervous activity. For full assessment of the biochemical peculiarities of apricots we investigated the content of $\beta$-carotene (provitamin A). In fruits with light yellow color of the pulp such as the Pineapple fruits the $\beta$-carotene content was $1.66 \mathrm{mg} / 100 \mathrm{~g}$, in case of intense yellow color, particularly in Red-Cheeked and Krasnodar late varieties, it was 3.05 and $3.52 \mathrm{mg} / 100 \mathrm{~g}$, respectively. The activity of polygalacturonase (PG) before computation of fruit for storage and during storage was also tested. The PG activity affecting fruit shelf life was the lowest at fruit harvesting. After 5 days of storage no PG activity was found in Sunny and Red-Cheeked varieties, while in Amber variety it increased slightly, indicating the varietal specificity. After 10 days of storage the PG activity increased and reached the maximum value by the day 15 being at peak in Sunny variety. Soluble pectins during storage were spent more intensively than protopectin, and in fruits with lower keeping quality, particularly in the Sunny variety, these processes were more active than in fruits with higher keeping quality, for instance in Amber variety. A $3.7 \%$ decrease in sugars during storage was detected in Sunny and Emerald varieties. The acid level decreased by $10.0 \%$ on average, and vitamin $\mathrm{C}$ and $\mathrm{P}-$ active catechin content became lower by 15.5 to $20.7 \%$. In Amber, Krasnodar late and Emerald plants the $\mathrm{C}$ vitamin activity remained relatively high. In Krasnodar late and Emerald apricot trees the $\beta$ carotene level did not change during storage. In the Sunny and Red-Cheeked varieties it decreased while in Amber increased slightly due to continuing maturation. At the end of storage a natural loss reached $6.8 \%$ in Amber and Emerald varieties and $10.2 \%$ in the Sunny variety. The best marketable quality at 60.0 and $57.4 \%$ rate of fruits of the highest commercial grade were observed in Amber and Krasnodar late varieties. The Sunny variety which annually accumulated ascorbic acid at a high level is recommended as a parental form in breeding for high vitamin $\mathrm{C}$ content.
\end{abstract}

Keywords: apricots, Krasnodar region, varietal characteristics, bioactive substances, storage, pectolytic enzymes.

Apricot (Armeniaca vulgaris Lam.) is a fruit crop grown in the southern regions and the Central Chernozem region of the Russian Federation. A biological 
feature of apricot is an early entry of flower buds in the flowering phase the timing of which ranged in the conditions of Krasnodar Territory from the first decade of March (1999) to the end of March (2011), that may affect both the value of the crop, and the quality of products. Apricot flowering is often accompanied by recurrent spring frosts or rainy and cloudy weather resulting in the onset of moniliosis (Monilia fruktigena Pers.), a dominant crop disease when flower buds are damaged partially or completely [1].

Currently, introduced varieties that are adapted to the conditions of the south of Russia are mainly grown at Kuban production plantations. The most common European varieties with average ripening such as Pineapple, Emerald, Red-Cheeked, Sunny, Amber, and Krasnodar late variety bred in the North Caucasian Regional Research Institute of Horticulture and Viticulture (SKZNIISiV) ripening in the second decade of July [2].

Apricot fruits contain a wide range of nutrient (sugar, acids) and prophylactic (vitamins, polyphenols, pectin) biologically active substances which not only have properties useful for human but also determine storage and ability to resist stress factors during vegetation [3-5]. The favorable effect of natural antioxidants on the quality kept under storage is confirmed by many authors dealing with storage of fruits of different cultures $[6,7]$. There is evidence that apricot fruits can be stored no more than 15 days $[1,6]$. The main reason for limiting period of storage is the damage by rot and decay from aging, which manifests itself in intensive softening of the fruit pulp, the loss of water and dissolved organic matter spent for breathing [8]. In this, cell turgor is reduced which results in tissue fading, enhancing decomposition processes in cells contained organic substances, in reduced resistance of fruit against microorganisms and reduced shelf life $[6,8]$.

In world practice, the methods of fruit preparation for storage using antioxidants are widespread, which allows to slow down the metabolic processes in the fruit and increase their resistance to stress factors, physiological diseases, and pathogens [7,9]. But the potential of the fruit themselves and their capacity for long-term storage are not always taken into account.

The purpose of our research is to study the specialty of chemical composition of the fruit in the apricot varieties from the gene pool of the North Caucasian Regional Research Institute of Horticulture and Viticulture and their impact on the quality of the commodity and biochemical values of fruit during their storage.

Tehnique. We studied the introduced apricot varieties of the Eastern European average ripening sub-group (Armeniaca vulgaris Lam.) mostly common in Krasnodar Territory such as Pineapple (origin unknown), Emerald, RedCheeked (seedlings of unknown origin), Sunny (obtained by crossing selected hybrid forms with different varieties of apricot), Amber (obtained by sowing seeds from open pollination of the Yerevani variety), and the late-ripening Krasnodar late variety bred in the North Caucasian Regional Research Institute of Horticulture and Viticulture (obtained from seedling D 113). Selection of fruit was held in the Experimental Production Farm (EPF) Tsentral'noe (Krasnodar) in 1999-2011. Many of the studied varieties are the basis for regionalized assortment of varieties and valuable source material for breeding for resistance to frost and diseases.

The study of soluble solids content (SS) was performed using a RL-3 refractometer (Poland); acids were assayed by titration of the prepared sample with $0.1 \mathrm{~N} \mathrm{NaOH}$ in the presence of phenolphthalein; sugars were analyzed by titration with the mixture of Felling solutions (I and II); ascorbic acid was estimated by titration of the samples with $0.001 \mathrm{~N} \mathrm{KIO}_{3}$; and for P-active compounds 
(catechins) measurement a KFK-3-01-ZOMZ photo colorimeter (Russia) was used according to the L.I. Vigorov method [10]. To measure the amount of $\beta$ carotene, extraction from fruit was performed with petroleum ether followed by colorimetry using a KFK-4 (Russia); the content of nicotinic acid (vitamin PP) was estimated by the color intensity under the interaction with thiocyanogen bromide and metol using a KFK-3-01-ZOMZ photo colorimeter (Russia). Polygalacturonase (PG) activity was measured using a KFK-3-01-ZOMZ each 5 days of storage starting from harvesting by the amount of destroyed pectin during enzymatic hydrolysis.

Apricots were stored according to Russian State Standard GOST 5051993 [11]. All experiments were performed in 3-fold replicates. Mathematical data processing was performed by descriptive statistics and analysis of variance using the Microsoft Excel and Mathcaal 11A software package.

Results. The study of apricots of the Eastern European subgroup showed varietal characteristics on almost all values of the fruit chemical composition. Thus, the amount of soluble solids (SS) ranged from 13.5 (Emerald variety) to $18.8 \%$ (Pineapple variety), and sugar content varied from 9.5 to $13.6 \%$, respectively (Table 1 ).

1. Main biochemical characteristics in the fruit of apricot varieties (Armeniaca vulgaris Lam.) ( $X \pm_{X}$, EPF Tsentral'noe, Krasnodar, 1999-2011)

\begin{tabular}{lcc|cc}
\hline \multicolumn{1}{c|}{ Variety } & SS, \% & Total sugar, $\%$ & Acidity, $\%$ & SAR \\
\hline Pineapple & $18.2 \pm 1.2$ & $13.6 \pm 1.0$ & $1.6 \pm 0.40$ & 8.1 \\
Emerald & $13.5 \pm 0.8$ & $9.5 \pm 0.8$ & $2.0 \pm 0.45$ & 4.7 \\
Red-Cheeked & $15.5 \pm 2.4$ & $10.9 \pm 0.6$ & $2.0 \pm 0.08$ & 5.4 \\
Krasnodar late & $15.2 \pm 0.8$ & $10.3 \pm 1.4$ & $1.4 \pm 0.08$ & 7.1 \\
Sunny & $18.0 \pm 2.2$ & $12.3 \pm 1.8$ & $1.7 \pm 0.10$ & 7.1 \\
Amber & $14.6 \pm 0.6$ & $9.8 \pm 0.6$ & $1.6 \pm 0.08$ & 5.7 \\
$\quad$ Average & $15.8 \pm 1.3$ & $11.1 \pm 1.0$ & $1.7 \pm 0.32$ & 6.4 \\
N o t e. SS means soluble solids, SAR is a sugar to acid ratio. & & \\
\hline
\end{tabular}

The fruit of the studied varieties were highly acidic as they contained from 1.4 (Krasnodar late) to $2.0 \%$ (Emerald, Red-Cheeked) organic acids including malic acid (up to $90.0 \%$ of total acids) and minor amounts of citric, lactic, and amber acids. These data were partially confirmed by the results of the research performed by E.F.L.J. Anet and T.M. Reynolds [12] who found quinic acid, other than those listed, in apricots.

The sugar to acid ratio (SAR) which characterizes the flavor quality of fruits varied from 4.7 relative units (r.u.) in the Emerald variety, which corresponds to the sour taste, to 8.1 r.u. in the Pineapple variety with sour-sweet fruit.

Apricot contains significant amounts of pectins, mainly in water-soluble form. Therefore, the ratio of soluble pectin to protopectin in most varieties was more than 1.0 r.u. (Table 2).

2. Content (\%) of pectin substances in the fruit of different apricot varieties (Armeniaca vulgaris Lam.) ( $X \pm X$, EPF Tsentral'noe, Krasnodar, 1999-2011)

\begin{tabular}{|c|c|c|c|c|}
\hline Variety & Soluble pectin & Protopectin & $\begin{array}{l}\text { Total pectin sub- } \\
\text { stances }\end{array}$ & $\begin{array}{l}\text { Ratio of pectin to } \\
\text { protopectin, r.u. }\end{array}$ \\
\hline Pineapple & $0.51 \pm 0.12$ & $0.51 \pm 0.11$ & $1.02 \pm 0.12$ & 1.00 \\
\hline Emerald & $0.50 \pm 0.10$ & $0.48 \pm 0.11$ & $0.98 \pm 0.10$ & 1.04 \\
\hline Red-Cheeked & $0.56 \pm 0.14$ & $0.46 \pm 0.10$ & $1.02 \pm 0.12$ & 1.20 \\
\hline Krasnodar late & $0.62 \pm 0.06$ & $0.57 \pm 0.14$ & $0.99 \pm 0.12$ & 1.09 \\
\hline Sunny & $0.45 \pm 0.06$ & $0.43 \pm 0.10$ & $0.88 \pm 0.08$ & 1.00 \\
\hline Amber & $0.68 \pm 0.14$ & $0.65 \pm 0.12$ & $1.33 \pm 0.12$ & 1.04 \\
\hline Average & $0.52 \pm 0.12$ & $0.52 \pm 0.11$ & $1.04 \pm 0.11$ & 1.06 \\
\hline
\end{tabular}

The important role of pectin in the fruit stability against physiological disorders under storage is related to their high water-holding capacity, by which the cell turgor is maintained [6]. We selected the Amber variety in which the 
content of pectin was stable regardless of the year of studies [3, 4].

Comparison of our data with the results obtained by Z.I. Kertesz [13] showed that most of the studied apricot varieties from Krasnodar Territory were not inferior to that grown in the United States in the content of total pectin in the fruit (in American varieties, it is an average of $1.03 \%$ ).

The vitamin composition is of great importance in antioxidant activity in fruits $[5,7]$. The vitamin complex of apricots has been found to contain water$(\mathrm{C}, \mathrm{P}, \mathrm{PP})$ and liposoluble ( $\beta$-carotene with vitamin A activity) compounds of different functional significance (Table 3).

3. Content $(\mathrm{mg} / 100 \mathrm{~g})$ of vitamins in the fruit in different apricot (Armeniaca vulgaris Lam.) varieties ( $X \pm X$, EPF Tsentral'noe, Krasnodar, 1999-2011)

\begin{tabular}{lrr|rrr}
\hline & Variety & \multicolumn{1}{c|}{$\mathrm{C}$} & \multicolumn{1}{c}{$\mathrm{P}$} & $\mathrm{PP}$ & $\beta$-carotene \\
\hline Pineapple & $17.3 \pm 2.50$ & $52.6 \pm 4.40$ & $0.55 \pm 0.04$ & $1.66 \pm 0.04$ \\
Emerald & $9.0 \pm 1.65$ & $155.9 \pm 3.82$ & $0.56 \pm 0.04$ & $2.15 \pm 0.04$ \\
Red-Cheeked & $11.6 \pm 1.10$ & $120.3 \pm 4.22$ & $0.43 \pm 0.02$ & $3.05 \pm 0.05$ \\
Krasnodar late & $13.5 \pm 2.04$ & $62.9 \pm 1.20$ & $0.50 \pm 0.03$ & $3.52 \pm 0.04$ \\
Sunny & $21.9 \pm 3.60$ & $45.6 \pm 2.22$ & $0.60 \pm 0.04$ & $2.62 \pm 0.04$ \\
Amber & $10.5 \pm 1.45$ & $154.4 \pm 3.86$ & $0.42 \pm 0.01$ & $2.36 \pm 0.02$ \\
$\quad$ Average & $14.0 \pm 2.05$ & $98.6 \pm 3.26$ & $0.51 \pm 0.03$ & $2.56 \pm 0.04$ \\
\hline
\end{tabular}

Note, the Pineapple and Sunny varieties accumulated a significant amount of ascorbic acid (17.3 and $21.9 \mathrm{mg} / 100 \mathrm{~g}$, respectively) exceeding the average content $(14.0 \mathrm{mg} / 100 \mathrm{~g})$ typical of the central zone of Krasnodar Territory.

The biological value of fruits can be judged by the accumulation of vitamin $\mathrm{P}$ which serves as a vitamin $\mathrm{C}$ synergist, increasing the biological effect of the latter. Many phenolic substances including catechins have P-vitamin activity [14-16]. P-active catechins were detected in fruits at 45.6 to $155.9 \mathrm{mg} / 100 \mathrm{~g}$ level. The high content of catechins at more than $100.0 \mathrm{mg} / 100 \mathrm{~g}$ was observed in Emerald, Red-Cheeked and Amber varieties.

One of the important properties of apricot fruits is a relatively high level of vitamin PP which is part of many enzymes involved in cellular respiration, protein metabolism, regulation of nervous activity [17]. Biochemical importance of vitamin PP is due to its use in the synthesis of coenzymes, the nicotinamide adenine dinucleotide $\left(\mathrm{NAD}^{+}\right)$and nicotinamide adenine dinucleotide phosphate $\left(\mathrm{NADP}^{+}\right)$that have owns one of the main roles in biological oxidation [6]. Some varieties (Emerald, Pineapple, Sunny) were found to contain over $0.55 \mathrm{mg}$ of vitamin PP per $100 \mathrm{~g}$. This allows attributing apricot to a group of crops with high biochemical parameters, since few of crops contain the same amount of vitamin PP and other vitamins [17].

One of the distinguishing features of apricot is the presence of carotenoid pigments. The studies of $\mathrm{H}$. Brockmann [18] for the first time found that apricot carotenoids consist mainly of $\beta$-carotene which has the highest biological activity and gives the fruits their valuable medicinal properties and nice appearance. Depending on the content of $\beta$-carotene, the studied fruits had light yellow pulp (Pineapple variety with $\beta$-carotene content of $1.66 \mathrm{mg} / 100 \mathrm{~g}$ ) or intense yellow pulp (Red-Cheeked and Krasnodar late varieties with $\beta$-carotene content of 3.05 and $3.52 \mathrm{mg} / 100 \mathrm{~g}$, respectively).

Analyzing the chemical composition of the species studied, we can conclude that the fruits of apricot provide the daily intake of vitamins, polyphenols and other components for various groups of the population [19].

Due to the problem of fruit storage, especially of stone fruit storage, to study of the activity of pectolytic enzymes including polygalacturonase (PG) which destroys the 1.4-glycoside bond in the demethoxylated pectin molecule (pectin acids) and influences the shelf life of fruits, is of great importance [6]. 
In the research the

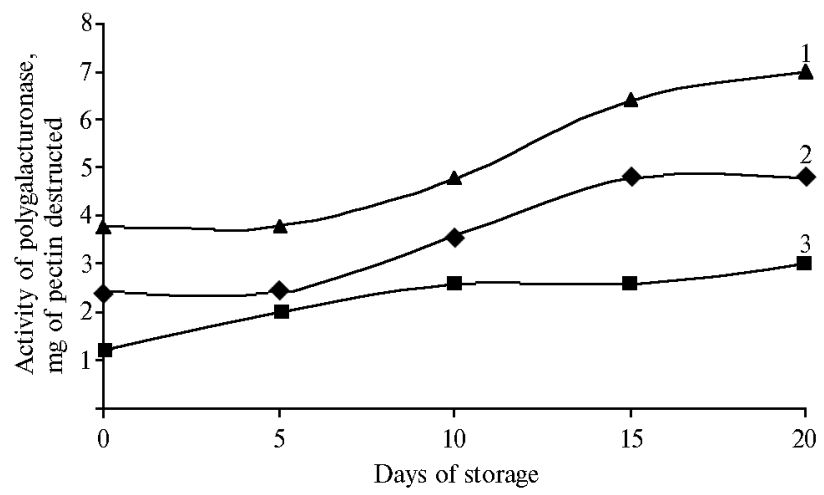

Fig. 1. Dynamics of changes in the activity of polygalacturonase in the fruit during their storage in refrigerating chambers in different varieties of apricot (Armeniaca vulgaris Lam.): 1, 2, 3Sunny, Red-Cheeked, Amber varieties (EPF Tsentral'noe, Krasnodar, 2011). lowest PG activity in fruit was demonstrated at harvesting. It was $1.2 \mathrm{mg}$ of destroyed pectin in the Amber variety, $2.4 \mathrm{mg}$ in the Red-Cheeked variety, and $3.8 \mathrm{mg}$ in the Sunny variety. After 5 day storage the PG activity was not found in Sunny and RedCheeked varieties, while in Amber variety it increased slightly (Fig. 1). The peak PG activity was found in the Sunny variety with $7.0 \mathrm{mg}$ of destroyed pectin found at the end of

the storage, while in the Amber variety the corresponding parameter did not exceed $3.0 \mathrm{mg}$. This suggests that the effect of enzymes is most active even at low (not more than $+2{ }^{\circ} \mathrm{C}$ ) storage temperature in the varieties the fruits of which contain the minimal amount of pectin.

These data indicate the variety specificity on the proteolytic enzymes' activity which cause disintegration of cell walls.

After 10 day storage the PG activity increased and reached its maximum by the day 15 . As a result of PG activity, the total amount of pectin in individual varieties decreased by more than $20.0 \%$ over 20 days of storage (Table 4).

4. Changes in the content $(\%)$ of pectin substances in the fruit of different apricot varieties (Armeniaca vulgaris Lam.) after 20 days storage in the refrigerator (EPF Tsentral'noe, Krasnodar, 2002-2011)

\begin{tabular}{l|c|c|c|c}
\hline \multirow{2}{*}{ Variety } & \multirow{2}{*}{ Prior to storage } & \multicolumn{3}{c}{ After storage } \\
\cline { 3 - 5 } & & total & soluble pectin & protopectin \\
\hline Pineapple & $0.51 \pm 0.12$ & $0.86 \pm 0.12$ & $0.46 \pm 0.06$ & $0.40 \pm 0.05$ \\
Emerald & $0.50 \pm 0.10$ & $0.90 \pm 0.12$ & $0.48 \pm 0.06$ & $0.42 \pm 0.05$ \\
Red-Cheeked & $0.56 \pm 0.14$ & $0.82 \pm 0.09$ & $0.50 \pm 0.06$ & $0.32 \pm 0.04$ \\
Krasnodar Later & $0.62 \pm 0.06$ & $0.85 \pm 0.10$ & $0.40 \pm 0.05$ & $0.45 \pm 0.05$ \\
Sunny & $0.45 \pm 0.06$ & $0.62 \pm 0.06$ & $0.32 \pm 0.05$ & $0.30 \pm 0.03$ \\
Amber & $0.68 \pm 0.14$ & $1.02 \pm 0.12$ & $0.52 \pm 0.06$ & $0.50 \pm 0.04$ \\
$\quad$ Average & $0.52 \pm 0.12$ & $0.84 \pm 0.10$ & $0.45 \pm 0.05$ & $0.40 \pm 0.04$ \\
\hline
\end{tabular}

The results showed that soluble pectins during storage were spent more intensively than protopectin, and in fruits with lower keeping quality (the Sunny variety), the amount of pectin substances changed more actively than in fruits with higher keeping quality. As a result, the peel of fruits in the Sunny variety at the end of storage becomes less elastic, flabby, and the pulp was spreadable.

During storage, the changes in the chemical composition of fruit were noted. A $3.7 \%$ decrease in sugars during storage was detected (Sunny and Emerald varieties), the acid level decreased by $10.0 \%$ on average, and vitamin $\mathrm{C}$ and P-active catechin content became lower by 15.5 to $20.7 \%$. In Amber, Krasnodar late and Emerald varieties, the $\mathrm{C}$ vitamin activity remained relatively high which confirms that the varietal characteristics are a major factor in determining not only the content but also the stability of ascorbic acid during storage. In the Krasnodar late and Emerald apricot varieties, the $\beta$-carotene level did not change during storage; in the Sunny and Red-Cheeked varieties it decreased from 2.62 to 2.54 and from 3.05 to $2.94 \mathrm{mg} / 100 \mathrm{~g}$, respectively; in the Amber 
variety it increased insignificantly due to the fruit ripening.
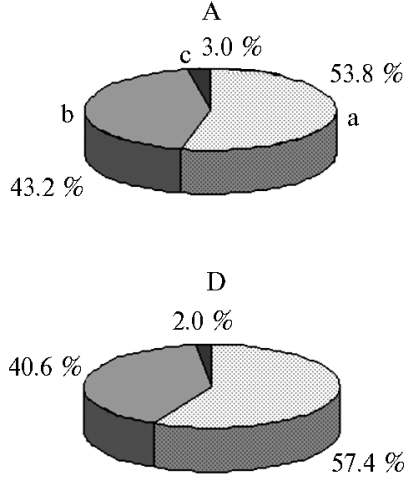
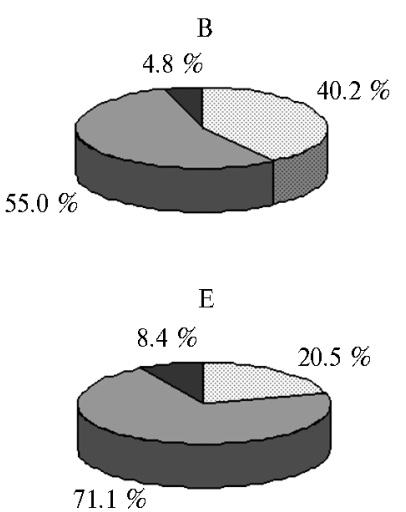
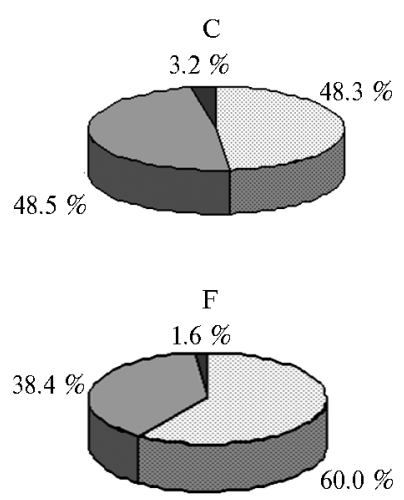

Fig. 2. Quality of the fruits in different apricot varieties (Armeniaca vulgaris Lam.) after 20 days storage in the refrigerator: A - Pineapple variety, B - Emerald variety, C - Red-Cheeked variety, $\mathrm{D}-$ Krasnodar late variety, $\mathrm{E}-$ Sunny variety, $\mathrm{F}-$ Amber variety; $\mathrm{a}-1^{\text {st }}$ commercial grade, $\mathrm{b}-$ $2^{\text {nd }}$ commercial grade, c - rot (EPF Tsentral'noe, Krasnodar, 2002-2011).

The natural loss, as one of the main indicators of preservation, at day 10 of storage was the greatest in the Amber and Sunny varieties (5.0 and 8.4\%, respectively) (Fig. 2). At the end of storage, the natural loss reached $6.8 \%$ in Amber and Emerald varieties and $10.2 \%$ in the Sunny variety. The best marketable quality was observed in the Amber and Krasnodar late varieties, the proportion of rot did not exceed $2.0 \%$. In Amber and Krasnodar late varieties, the proportion of the $1^{\text {st }}$ commercial grade fruits was 53.8 and $48.3 \%$, respectively.

Thus, the chemical composition of the fruits of the apricot varieties studied grown in the conditions of the central area of Krasnodar Territory provides the daily rate of consumption of vitamins, polyphenols, and pectin, which determine the therapeutic and prophylactic properties of the food product. The Amber and Krasnodar late varieties stood out among the samples, as the quality of the fruit was maintained in refrigerators for 20 days. It is promoted by the high content of biologically active substances and low activity of polygalacturonase in fruit tissues, and as a result they remain more compact which allows to attribute such products to the $1^{\text {st }}$ commercial grade. The Sunny variety which annually accumulated ascorbic acid at a high level is recommended as a parental form in breeding for high vitamin $\mathrm{C}$ content.

\section{REFEREN C ES}

1. Abrikos /Pod redaktsiei V.K. Smykova [Apricot trees. V.K. Smykov (ed.)]. Moscow, 1989.

2. D rag a v s e va I.A., Pri c h k o T.G., C h a la y a L.D., Y a k u b a G.V. Rekomendatsii po vozdelyvaniyu abrikosa $v$ Krasnodarskom krae [Apricot tree plantations in Krasnodar Krai: practical guidance]. Krasnodar, 2009.

3. $\mathrm{C}$ h a $\mathrm{l}$ a y a L.D. V sbornike nauchnykh trudov: Plodovodstvo, tom 22 [In: Pomiculture. V. 22]. RUP Institut plodovodstva, Samokhvalovichi (Balarus'), 2010: 232-241.

4. Chal ay a L.D., Prich ko T.G. Pokazateli kachestva plodov abrikosa razlichnykh pomologicheskikh sortov. LAP LAMBERT, Academic Publishing, Germany, 2013.

5. Gudk ovski i V.A. V sbornike: Osnovnye itogi i perspektivy nauchnykh issledovanii VNIIS im. I. V. Michurina. Tambov, 2001: 76-86.

6. Metlitski i L.V. V sbornike: Osnovy biokhimii plodov i ovoshchei [In: Biochemistry basics for fruits and vegetables]. Moscow, 1976: 349.

7. Van der Stujs A.A., Dekker M., d e J age r A., Jonger W.M.F. Activity and concentration of polyphenolic antioxidant in apple: effect of cultivar harvest year, and storage conditions. Arg. Food Chem., 2001, 49(8): 3606-3013 (doi: 10.1021/jf001493u).

8. F e d o r o v M.A. Promyshlennoe khranenie plodov [Industrial fruit storage]. Moscow, 1981.

9. S $\mathrm{ch}$ mit z M. Bedeutung von Vitaminen fur die Abwehr Tagikeits bericht 1992-1993 (Institut fur 
Obstbau und Gemusebau der Rheinischen Friedrich-Wiheims-Universitat). Bonn, 1994: 42-43.

10. Vig o rov L.I. Trudy III Vsesoyuznogo seminara po biologicheski aktivnym veshchestvam plodov i yagod [Proc. III Seminar on bioactive substances in fruits and berries]. Sverdlovsk, 1968: 480-492.

11. Abrikosy. Rukovodstvo po khraneniyu v kholodil'nykh kamerakh. GOST R 50519-93 [Apricot storage in the cold stors: guidance. RF State Standards R 50519-93]. Moscow, 1993.

12. An et E.F.L.J., Reynolds T.M. Water-soluble constituents of fruit. II. The separation of acids on anion-exchange resins: the isolation of L-quinic acid from Apricots. Austral. J. Chem., 1955, 8(2): 267-275.

13. Ke rte s Z Z.I. The pectic substances. NY, 1951.

14. Fukuda T., I to H., Yoshida T. Antioxidative polyphenols from walnuts (Juglans regia L.). Phytochemistry, 2003, 63: 795-801.

15. U p a d y s h e v M.T. Rol' fenol'nykh soedinenii v protsessakh zhiznedeyatel'nosti sadovykh rastenii [The role of phenolics in vital functions of garden plants]. Moscow, 2008.

16. Kalt W., Kush ad M.M. The role of oxidative stress and antioxidants in plant and human health: introduction to the colloquium. Hort. Sci., 2000, 35: 572.

17. Sk u rikhi n I.M. Tablitsy soderzhaniya aminokislot, zhirnykh kislot, vitaminov, makro- $i$ mikroelementov, organicheskikh kislot i uglevodov. Khimicheskii sostav pishchevykh produktov (spravochnik). Kniga 2 [Chemical composition of foods: handbook. Book 2]. Moscow, 1987.

18. B r o c k ma n n H. Die Sarotinoide der Apricose. Zeitschrift fur Physiologishe Chemie, 1933, 45: 215.

19. Metodicheskie rekomendatsii MR 2.3.1.2432-08. Normy fiziologicheskoi potrebnosti $v$ energii $i$ pishchevykh veshchestvakh dlya razlichnykh grupp naseleniya [Physiologically based requirements in energy and nutrients for different groups of the population: quidelines MR 2.3.1.243208]. Moscow, 2008. 